\title{
Deficit in Adipose Differentiation in Mesenchymal Stem Cells Derived from Chronic Rhinosinusitis Nasal Polyps Compared to Nasal Mucosal Tissue
}

\author{
Emanuela Chiarella ${ }^{1,+}$ (D) Nicola Lombardo ${ }^{2,+} \mathbb{\infty}$, Nadia Lobello ${ }^{2}$, Giovanna Lucia Piazzetta ${ }^{2}$, \\ Helen Linda Morrone ${ }^{1}$, Maria Mesuraca ${ }^{1, *(D)}$ and Heather Mandy Bond $1, * \mathbb{D}$ \\ 1 Laboratory of Molecular Haematopoiesis and Stem Cell Biology, Department of Experimental and Clinical \\ Medicine, University “Magna Græcia”, 88100 Catanzaro, Italy; emanuelachiarella@unicz.it (E.C.); \\ helen.morrone@gmail.com (H.L.M.) \\ 2 Otolaryngology Head and Neck Surgery, Department Medical and Surgical Sciences, \\ University “Magna Græcia”, 88100 Catanzaro, Italy; nlombardo@unicz.it (N.L.); \\ nadialobello@gmail.com (N.L.); giovannapiazzetta82@gmail.com (G.L.P.) \\ * Correspondence: mes@unicz.it (M.M.); bond@unicz.it (H.M.B.) \\ + These authors contributed equally to this work.
}

Received: 10 November 2020; Accepted: 1 December 2020; Published: 3 December 2020

\begin{abstract}
Chronic rhinosinusitis of the nasal mucosa is an inflammatory disease of paranasal sinuses, which causes rhinorrhea, nasal congestion, and hyposmia, and in some cases, it can result in the development of nasal polyposis. Nasal polyps are benign lobular-shaped growths that project in the nasal cavities; they originate from inflammation in the paranasal mucous membrane and are associated with a high expression of interleukins (IL)-4, IL-5, IL-13, and IgE. Polyps derive from the epithelial-mesenchymal transition of the nasal epithelium resulting in a nasal tissue remodeling. Nasal polyps from three patients with chronic rhinosinusitis as well as control non-polyp nasal mucosa were used to isolate and cultivate mesenchymal stem cells characterized as $\mathrm{CD}_{3}{ }^{+}, \mathrm{CD}^{+} 0^{+}$, $\mathrm{CD} 105^{+} / \mathrm{CD}^{-} 4^{-}, \mathrm{CD} 34^{-}$, and CD45 ${ }^{-}$. Mesenchymal stem cells (MSCs) cultures were induced to differentiate toward adipocytes, where lipid droplets and adipocyte genes PPAR $\gamma 2$, ADIPO-Q, and FABP4 were observed in control non-polyp nasal mucosa-derived mesenchymal cells but were scarcely present in the cultures derived from the nasal polyps, where apoptosis was evident. The modulation of the response to adipogenic stimulus in polyps represents a change in the molecular response that controls the cascade required for differentiation as well as possible means to specifically target these cells, sparing the normal mucosa of the nasal sinuses.
\end{abstract}

Keywords: nasal polyps; mesenchymal cells; adipocyte differentiation; apoptosis

\section{Introduction}

Chronic rhinosinusitis (CRS) is a frequent medical condition that adversely affects the quality of life of patients causing nasal obstruction and congestion, nasal drainage, facial pain or pressure, and hyposmia/anosmia [1], and it is supported by heterogeneous inflammatory processes. CRS can be divided into cases without nasal polyposis (CRSsNP) and CRS with nasal polyposis (CRSwNP) [2]. The cases can be categorized into different subtypes depending on the Th2 versus Th1/Th17 cell response together with the sets of cytokines, chemokines, and growth factors involved [3] and resulting in a balance of endotype and phenotypes, as described in the guidelines of the EPOS 2020 [4,5]. Nasal polyps are noncancerous lesions originating from the mucosa of the nasal sinuses. They hang down in a manner similar to teardrops and appear as soft and painless growths. The development of nasal polyps is the consequence of chronic inflammation affecting the mucous membranes in 
the paranasal sinuses and is caused by a multitude of stimuli including viruses, bacteria, fungi, and allergens [6]. Additionally, it can be associated with several risk factors: allergies, drug sensitivity, asthma, exposition to airborne irritants, immune system disorders, viral infections, or deviated septum or enlarged turbinates. When the growths become large, they can cause breathing difficulties, a reduced sense of smell or taste, and recurrent infections [1].

CRSwNP and CRSsNP conditions have different immunological cytokine profiles that are also associated with geographical and race variations [7]. The inflammatory pattern of CRSwNP has revealed a tissue eosinophilia mediated by Th2 cytokines and is associated to a high asthma prevalence rate. CRSwNP, compared to CRSsNP, shows increased levels of Th2 mediators including interleukin(IL)-4, IL-5, IL-13, IgE and eotaxin-2 [4,8]. These cytokines can be therapeutic targets using blocking monoclonal antibodies [9-13].

The tissue remodeling in nasal polyps is traceable to epithelial-mesenchymal transition (EMT) a biological process in which epithelial cells, undergoing biochemical changes, acquire mesenchymal and fibroblast-like properties with reduced intercellular adhesion and increasing migratory capacity, invasiveness as well as elevated resistance to apoptosis [14]. These nasal polyps can be a novel source of mesenchymal stem and progenitor cells, which can be isolated from small surgical biopsies [15].

Mesenchymal stem cells derived from polyps (NPO-MSCs) meet the basic criteria for typical MSCs, including (I) adherence to plastic culture plates; (II) high expression for the cell surface markers CD90, CD73, and CD105 and the absence of MHC-II (class of major histocompatibility complex), CD45, $\mathrm{CD} 34, \mathrm{CD} 14$, or CD11b surface antigens; and (III) multipotential ability to differentiate toward mature osteoblasts, adipocytes, and chondroblasts in vitro [16-20].

Here, we have isolated and characterized mesenchymal stem cells from nasal polyps (NPO-MSCs) by polypectomy endoscopic surgery procedures and from non-polyp nasal mucosa tissue of the same patient (CTL-MSCs). These nasal MSCs have similar phenotypes and growth rates and express CD90, CD73, and CD105. Results show that under adipogenic stimuli, NPO-MSCs compared to nasal tissue-derived MSCs (CTL-MSCs) are hardly able to differentiate into adipocytes and instead undergo apoptosis.

Our data provide new biological and molecular information on the behavior of NPO-MSCs during differentiation, which is useful for investigating molecular mechanisms underlying the development of nasal polyps, including mesenchymal-epithelial transition. The response to adipocyte differentiation stimulus where the NPO-MSCs fail to form adipocytes and cell death is activated by apoptosis represents a targeting mechanism for the polyps not affecting the non-polyp nasal mucosa tissue of the same patient.

\section{Results}

Polypectomy endoscopic surgery was performed on three different CRSwNP patients; to remove polyps, this treatment will give temporary relief, but the prediction is that they will reoccur within months, as the primary cause has not been addressed. Mesenchymal stem cells were purified from nasal polyps (NPO-MSCs), which are typically translucent pink with a lobus grape-like structure; an example is shown in Figure 1A together with a small piece of nasal mucosa tissue used as a control. CTL-MSCs and NPO-MSCs were derived from surgical biopsies of three different patients with CRSwNP, and clean monolayers of cells were obtained after 3 weeks of culture (Figure 1A). These cells were tested for cellular proliferation and were found to have similar growth rates being derived either from the control or polyp tissues in all three of the patients analyzed (Figure 1B). Cultures were characterized for mesenchymal phenotype by FACS being uniformly positive for the mesenchymal markers CD73, CD90, and CD105 and negative for CD14, CD34, and CD45 (Figure 1C). 
A

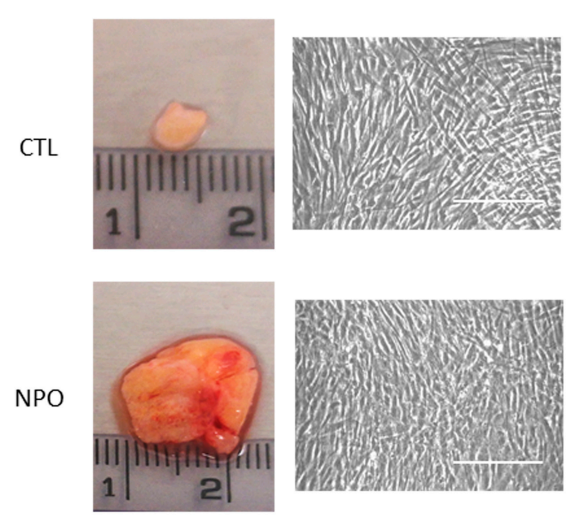

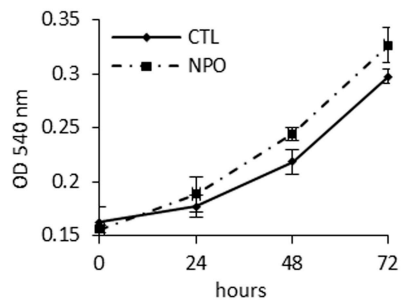

C
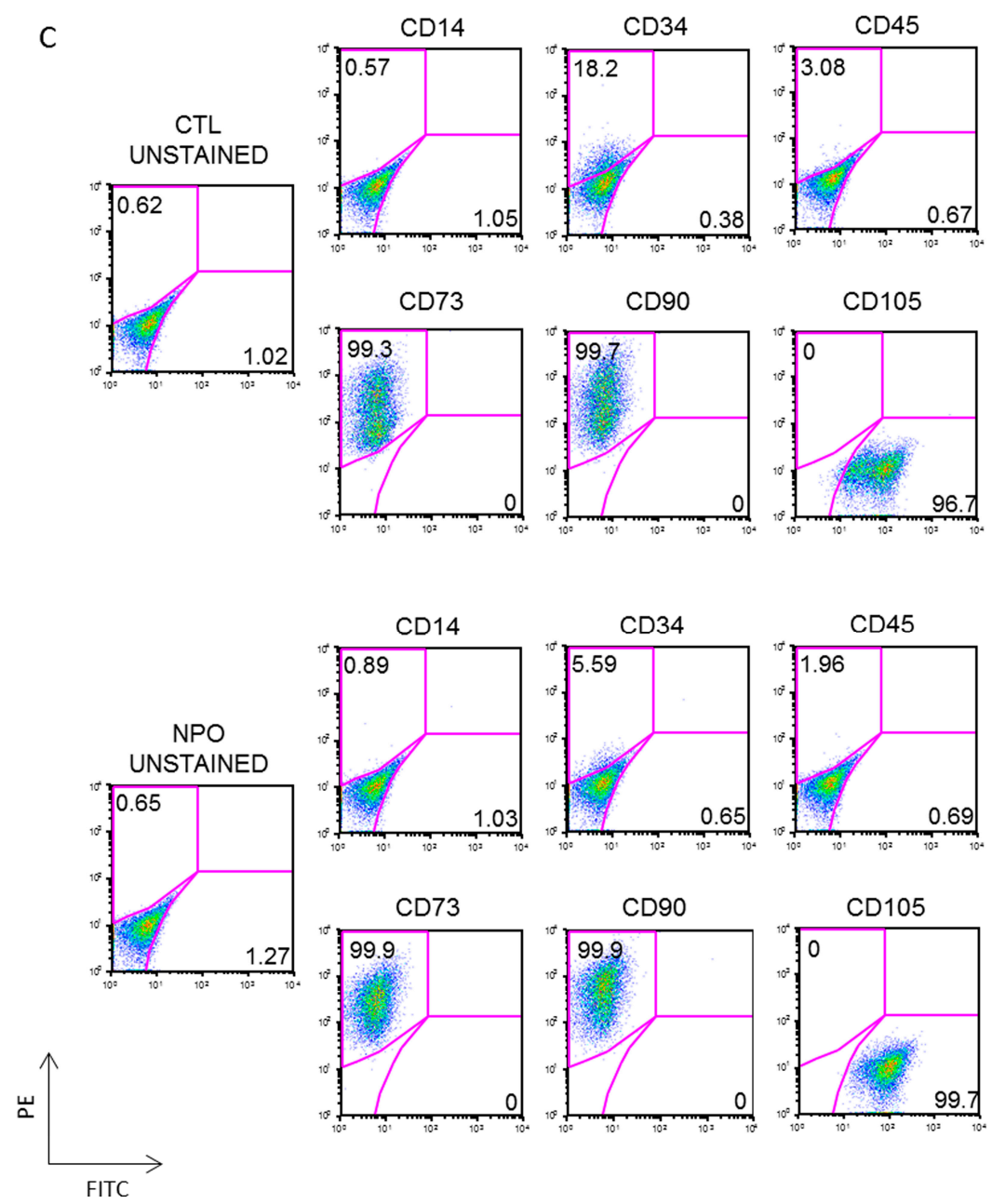

Figure 1. Isolation and characterization of mesenchymal stem cells from nasal polyps and nasal mucosa tissue. (A) Representative nasal biopsies from a patient with chronic rhinosinusitis (CRS). Polyps-derived mesenchymal stem cells were obtained by mechanical dissociation and collagenase digestion of the tissues. The morphology of adherent cells after three passages was observed by phase contrast microscope $(20 \times)$ Scale bar indicates $100 \mu \mathrm{m}$. (B) The growth rates of mesenchymal stem cells from non-polyp nasal mucosa tissue (CTL-MSCs) and mesenchymal stem cells from nasal polyps from the same patient (NPO-MSCs) were analyzed by 3-(4,5-dimethyl-2-thia-zolyl)-2, 5-diphenyl-2H-tetrazolium bromide (MTT) assays. (C) The phenotypic pattern for CD73, CD90, and CD105 expression was investigated by FACS analysis. 
Considering the capacity of mesenchymal cells to differentiate particularly into adipocytes, we tested both the nasal mucosa tissue-derived mesenchymal stem cells CTL-MSCs and the NPO-MSCs with standardized adipogenesis differentiation medium. It was found that after 14 days, the control nasal tissue-derived MSCs had a significant number of typical adipocytes where by phase contrast, lipid droplets were visible in many cells that were positive for Oil Red O staining (Figure 2A). However, it was notable that the NPO-MSCs scarcely formed lipid droplets with only a minimal amount of Oil Red O staining, and their morphology had changed with a spinodal-like appearance with less cell contacts.

A
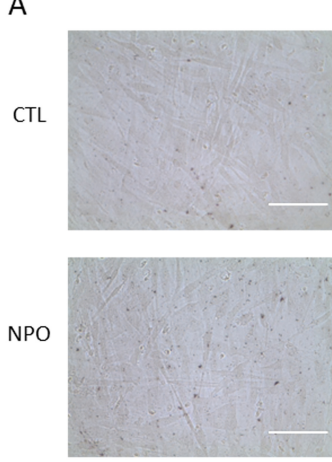

UNDIFFERENTIATED CELLS
PZ1

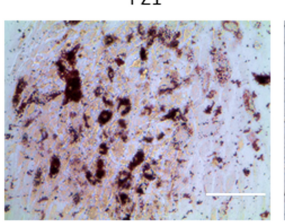

PZ2
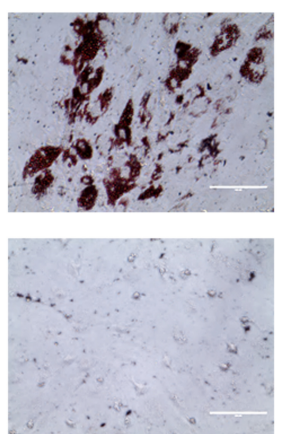

ADIPOCYTE DIFFERENTIATION - OIL RED O STAINED CELLS
PZ3
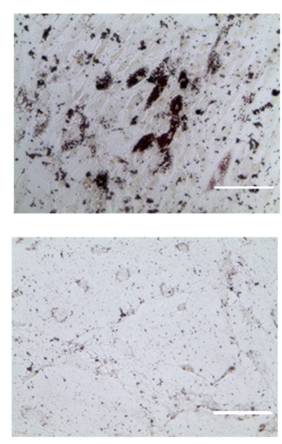

PZ 2 PZ 3

B PZ 1
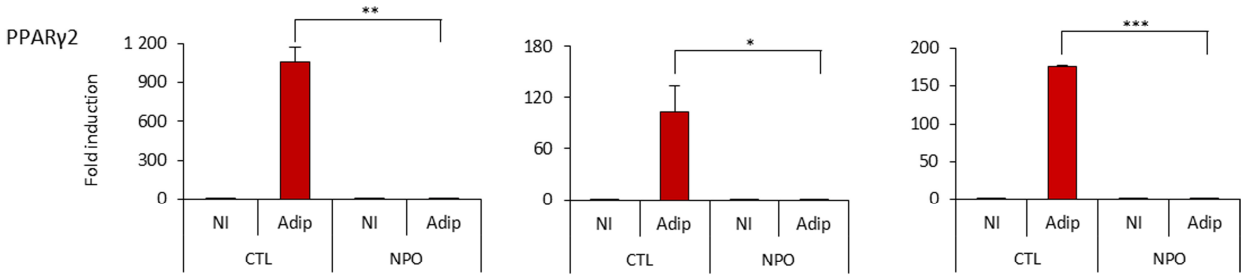

ADIPO-Q
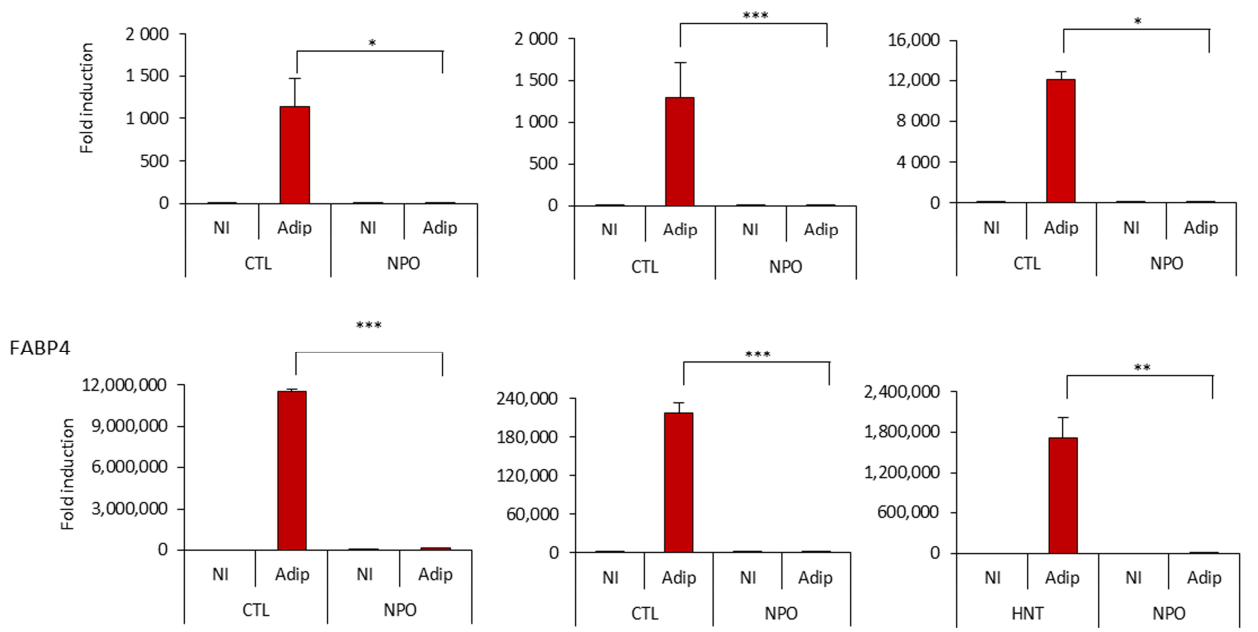

Figure 2. Adipocyte differentiation of CTL-MSCs and NPO-MSCs. (A) Mesenchymal stem cells were cultivated in either proliferation MesenPRO RS ${ }^{\mathrm{TM}}$ medium (non-induced, NI) or in STEM PRO ${ }^{\circledR}$ adipogenesis differentiation medium (Adip) for 14 days, stained with Oil Red O, and observed by phase contrast microscopy (20x) Scale bar indicates $1000 \mu \mathrm{m}$. The assay was performed in triplicate. (B) PPAR $\gamma 2$, ADIPO-Q, and FABP4 expression were quantified by RT-Q-PCR after 10 days of adipocyte differentiation. The gene expression was normalized for the housekeeping gene GAPDH (Glyceraldehyde-3-phosphate dehydrogenase). Data are represented as means \pm SD from three different experiments performed in duplicate $\left({ }^{*} p<0.05\right.$; ${ }^{* *} p<0.001$; $\left.{ }^{* * *} p<0.0001\right)$. 
Adipogenesis requires the sequential activation of key transcription factors resulting either in an induction of genes involved in lipid metabolism or an inhibition by transcription factors that can block the onset of differentiation [21]. These nasal MSCs cultures were tested for the modulation of the master transcription factor for adipogenesis PPAR $\gamma 2$ (peroxisome proliferator-activated receptors) [22] (Figure 2B), which was upregulated in the CTL-MSCs during differentiation, but not from polyps. Similarly, markers of fat metabolism - fatty acid binding protein 4 (FABP4), a carrier protein for fatty acids [23], and adiponectin (Adipo-Q) [21], which is exclusively expressed in adipose tissue being present in the plasma acting as an adipokine controlling fat metabolism and insulin sensitivity-were also induced from non-existent to high levels in the control nasal MSCs during differentiation, but they were only induced to a minimal level in the NPO-MSCs.

These cells were additionally tested in parallel for apoptosis. After 5 days, early apoptosis, analyzed by annexin $\mathrm{V}$ and PI staining, was evident in the cells derived from the nasal polyps and minimally in those from the CTL-MSC (Figure 3A). This was the case for all the three patients with control, and polyp-derived nasal MSCs and was at least almost three times more than evident in that from the nasal polyp-derived cells (Figure 3B). Late apoptosis and necrosis were only present at practically background levels, as reported in the table shown in Figure 3C.

A

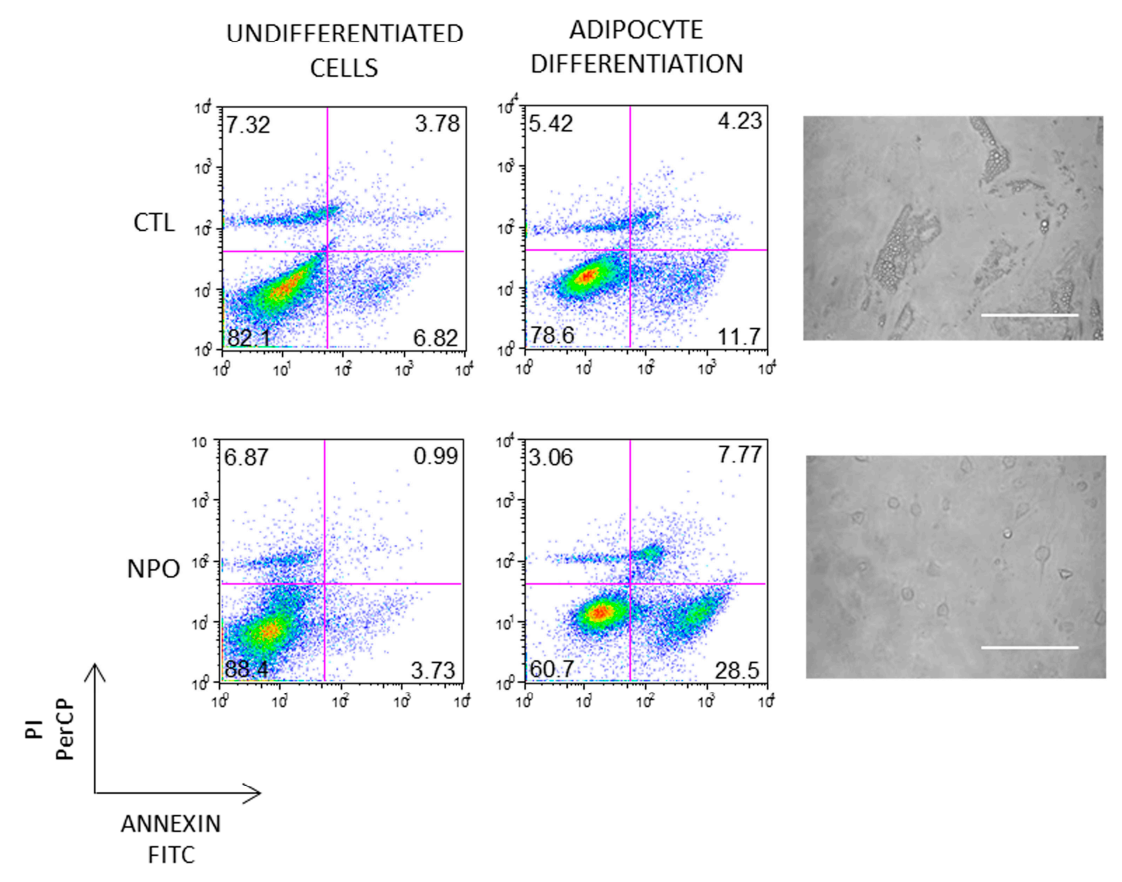

B

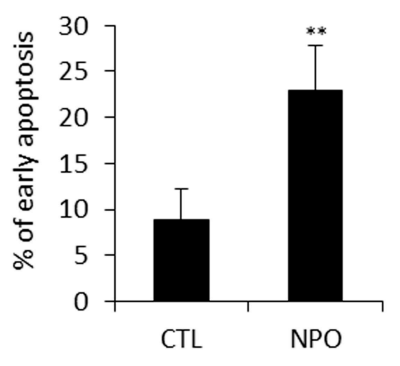

C

\begin{tabular}{|c|c|c|c|c|c|c|}
\hline \multirow{2}{*}{$\begin{array}{c}\text { Proliferation } \\
\text { condition }\end{array}$} & \multicolumn{2}{|c|}{ PZ1 } & \multicolumn{2}{|c|}{ PZ2 } & \multicolumn{2}{|c|}{ PZ3 } \\
\hline & CTL & $\mathrm{NPO}$ & CTL & $\mathrm{NPO}$ & CTL & $\mathrm{NPO}$ \\
\hline Early apoptosis (\%) & 6.82 & 3.73 & 7.61 & 4.88 & 2.73 & 2.3 \\
\hline Late apoptosis (\%) & 3.78 & 0.99 & 4.68 & 9.92 & 5.5 & 6.35 \\
\hline Necrosis $(\%)$ & 7.32 & 6.87 & 2.02 & 1.03 & 0.84 & 0.89 \\
\hline \multirow{2}{*}{$\begin{array}{c}\text { Adipocyte } \\
\text { differentiation }\end{array}$} & \multicolumn{2}{|c|}{ PZ1 } & \multicolumn{2}{|c|}{ PZ2 } & \multicolumn{2}{|c|}{ PZ3 } \\
\hline & CTL & NPO & CTL & NPO & CTL & NPO \\
\hline Early a poptosis (\%) & 11.7 & 28.5 & 9.7 & 19.6 & 5.36 & 20.6 \\
\hline Late apoptosis (\%) & 4.23 & 7.7 & 2.75 & 3.6 & 1.02 & 2.01 \\
\hline Necrosis (\%) & 5.42 & 3.06 & 2.74 & 1.63 & 2 & 2.24 \\
\hline
\end{tabular}

Figure 3. NPO-MSCs undergo apoptosis when cultured in adipocyte differentiation medium. 
(A) CTL-MSCs and NPO-MSCs were cultivated in either proliferation conditions (non-induced CTL) or in adipocyte differentiation medium. Images are in phase contrast and scale bar indicates $100 \mu \mathrm{m}$. Cells were stained for both annexin V and PI to evaluate early apoptosis, late apoptosis, and necrosis and analyzed by FACS. The results of early apoptosis are represented as means \pm SD from three different experiments and $(\mathbf{B}, \mathbf{C})$ the percentage of early apoptosis and late apoptosis/necrosis are indicated in the table for each patient $\left.{ }^{* *} p<0.001\right)$.

\section{Discussion}

Mesenchymal stem cells purified from adipose tissue (ADSCs) and bone marrow (BM-MSCs) are known for their potentiality to differentiate in multi-lineages toward mature osteoblasts, adipocytes, chondroblasts, and neuronal-like cells [24-26]. Diverse experimental cellular tissues have been explored to obtain mesenchymal cells with potential for inherent differentiation, which may result into unique phenotypes. The use of adult somatic cells that can transdifferentiate can avoid using embryonic stem cell systems, which raises ethical issues. Nasal polyps are relatively frequent in CRS and have to be surgically removed periodically. They represent a discarded tissue for potential experimental and clinical exploration.

In this manuscript, mesenchymal cells from nasal polyps from three different CRS patients (NPO-MSCs) are compared to MSCs derived from nasal mucosal tissue (CTL-MSCs) for their ability to differentiate toward adipose tissue. Even though the NPO-MSCs were characterized as having the mesenchymal markers CD73, CD90, and CD105 similar to CTL-MSCs, we showed that they have a considerably reduced ability to form characteristic lipid-filled adipocytes and undergo a significant degree of early apoptosis. Instead, the CTL-MSCs form typical adipocyte cultures with groups of cells staining strongly for Oil Red O. This is similar to those found stimulated with adipocyte differentiation medium derived from ADSCs cells [27-29].

Previous studies by Cho KS et al. [30] have used normal nasal tissue from healthy patients as a source of mesenchymal progenitor cells (MPCs) equivalent to MSCs from paranasal sinus mucosa and compared them with properties of MPCs of other tissue sources within the sinonasal cavity. MPCs were in the maxillary sinus (MS) and ethmoid sinus (ES) as well as the inferior turbinate (IT) and tonsils from the normal nasal cavity. These cultures from MS-, ES-, IT-, and T-MPCs yielded mesenchymal cells with similar morphologies and phenotypes, which are capable of distinct adipogenic, osteogenic, and chondrogenic differentiation abilities. The colony-forming potential and proliferation capability of ES-MPCs were distinctly higher than other MPCs.

Nasal polyp MSCs-derived cells, described by Cho JS et al. [17], can be induced to differentiate toward osteogenic, adipogenic, chondrogenic, and neural-like cells. Chondrocytic and osteogenic cells have robust colorations (alcian blue and alizarin red), whereas the adipocyte Oil Red O staining was evident, but the cells lacks translucent lipid droplets that can be found from ADSC or BM-MSCs. There were increases in FABP4 and PPAR $\gamma 2$ mRNAs [17] in induced cells, but the levels of expression are difficult to compare with other sources of MSCs, as the increases are as fold above a negative background. Additionally, neural induction was observed after 3 weeks by antibody staining of Class III B tubulin and the neural filaments NF-L and NF-H. In this case [17], the differentiation was compared to the non-induced proliferating polyp cells rather than with normal nasal tissues.

Gene expression tools and proteomic analysis are substantially contributing to clarify the features of mesenchymal stem cells and the protein cross-talk responsible for stemness [16,24,31]. MSCs were isolated [16] from nasal polyp tissue, and their gene expression profile and immune phenotype were compared with BM-MSCs. These MSCs cells were both found to have characteristic features of MSCs, expressing the cell surface antigens CD73, CD90, CD105, and ability to differentiate toward osteocytes and adipocytes [24]. Nasal PO-MSCs expressed higher levels of stem cells specific markers (CD133 and ABCB1), while BM-MSCs showed an elevated expression of cytokines and growth factors (FGF10, KDR, and GDF6), and PO-MSC displayed genes related to matrix remodeling process as found in polyps. Several MSCs immune-associated membrane markers CD117, HLA-DR, PD-L1, and PD-L2 
were not expressed in PO-MSCs but were highly present in BM-MSCs. These markers are mainly associated with the immunoregulatory capacity of MSCs.

These observations indicate that a classification as mesenchymal stem cells only partly defines the cell type, which will retain features and genes derived from the original tissue [24,26]. Adipocyte differentiation, although evident, has several limitations in terms of quantification: although it can be clearly seen by phase contrast and stained by Oil Red $\mathrm{O}$, the number of adipocytes forming is difficult to estimate, as the adipocytes develop in patches rather than covering the entire dish/well. It is also difficult to compare absolute PCR gene expression data for adipocyte gene expression as the induction is from nothing to very high levels. This aspect is further complicated by different controls being used in the published manuscripts discussed, nasal polyp MSCs vs. MS-, ES, IT-, and T-MPCs mesenchymal cells $[17,30]$, nasal polys vs. BM-MSCs [16], and here, nasal polyps (NPO-MSCs) vs. nasal mucosal tissue (CTL-MSCs) from the same patient. Additionally, the interpretation of these results is limited, considering that the majority of protocols use a commercial mix of differentiation stimulants from Gibco, Millipore, and here StemPro ${ }^{\circledR}$ adipogenesis medium from Thermo Fisher Scientific (Monza, Italy), which on the one hand standardizes the procedure and gives a high probability of the differentiation working; however, it precludes the determination of which biomolecule/concentration/solvent is critical in the cocktail in a particular cellular setting.

\section{Materials and Methods}

\subsection{Mesenchymal Stem Cells (MSCs) Isolation and Culture}

MSCs cells were obtained from nasal polyps $(0.7-0.9 \mathrm{~cm})$ of CRS patients (CRSwNP) and controls from the same patient of nasal mucosal tissue $(0.2-0.3 \mathrm{~cm})$, which was non-polypoid. Cells were extracted by mechanical dissociation, using a scalpel blade followed by enzymatic digestion with Collagenase IV $1 \mathrm{mg} / \mathrm{mL}$ for $4-12 \mathrm{~h}$ at $37^{\circ} \mathrm{C}$. Cells were washed in PBS (Phosphate-buffered saline) and filtered through $70 \mu \mathrm{m}$ filters and adherent cells were cultivated in tissue culture treated 6 wells plates in MesenPRO RS ${ }^{\mathrm{TM}}$ medium (cat no. 12746-012 Thermo Fisher Scientific), 1× Glutamax (Life Sciences, Monza, Italy), 50U of penicillin $/ 50 \mu \mathrm{g}$ streptomycin $/ \mathrm{mL}$ and gentamicin $20 \mu \mathrm{g} / \mathrm{mL}$ and then incubated at $37^{\circ} \mathrm{C}$ in $5 \% \mathrm{CO}_{2}$. After three passages, a uniform monolayer of adherent cells was obtained. Informed consent was obtained from donors given by patients.

\subsection{Flow Cytometry and Apoptosis}

MSCs cells were stained with fluorescent-conjugated antibodies for CD14, CD34, CD45, CD73, CD90, and CD105 (Miltenyi Biotec S.r.l., Bologna) by incubating with each antibody for $30 \mathrm{~min}$, in the dark, at $4{ }^{\circ} \mathrm{C}$ and washed with PBS. Cells were re-suspended in $300 \mu \mathrm{L}$ of PBS, acquired on the BD FACscan ${ }^{\mathrm{TM}}$ II, and data were analyzed with FlowJo software 8.8.6 (Becton Dickinson, Milan, Italy) [32].

\subsection{Annexin V/Propidium Iodide (PI) Staining Assay}

Apoptosis was evaluated using the kit from Life Technologies (Monza, Italy), an FITC (Fluorescein isothiocyanate) Annexin V apoptosis detection kit with Propidium Iodide (PI) staining after 5 days of culture, according to the manufactures instructions. Briefly, after 5 days of culture, $5 \times 10^{5}$ cells were washed once with cold PBS and resuspended in $100 \mu \mathrm{L}$ of binding buffer containing $5 \mu \mathrm{L}$ of annexin V-FITC and $1 \mu \mathrm{L}$ PI $(100 \mu \mathrm{g} / \mathrm{mL})$ for $15 \mathrm{~min}$ in the dark at room temperature. The samples were re-suspended in $400 \mu \mathrm{L}$ of annexin $\mathrm{V}$ binding-buffer diluited to $1 \times$ with $\mathrm{H}_{2} \mathrm{O}$ for Flow Cytometry analysis (BD FACScan $\mathrm{II}^{\mathrm{TM}}$ ). The percentage of cells in early apoptosis or late apoptosis/necrosis was evaluated by gating annexin $\mathrm{V}^{+} / \mathrm{PI}^{-}$and annexin $\mathrm{V}^{+} / \mathrm{PI}^{+}$labeled cells, respectively, using FlowJo software 8.8.6 [33]. 


\subsection{Cell Proliferation Assay}

Cell proliferation was measured by the MTT assay which uses tetrazolium salt (3-(4,5-dimethyl-2-thia-zolyl)-2, 5-diphenyl-2H-tetrazolium bromide). Briefly, $5 \times 10^{2}$ cells/well were seeded in $100 \mu \mathrm{L}$ of MesenPro RS ${ }^{\text {TM }}$ onto 96-well plates and assayed one to three days after incubation. The cells were treated with $10 \mu \mathrm{L}$ of MTT reagent $(5 \mathrm{mg} / \mathrm{mL}$ ) (Sigma Aldrich, Milan, Italy) at $37^{\circ} \mathrm{C}$ for $90 \mathrm{~min}$ and then treated with the addition of $110 \mu \mathrm{L}$ of isopropanol prepared with $0.08 \mathrm{~N} \mathrm{HCl}$, which was added to block the reaction by cell lysis and solubilization of the formazan crystals. The colorimetric reaction was detected at $590 \mathrm{~nm}$ using the spectrofotometer Glomax (Promega, Milan, Italy). The absorbance registered was directly proportional to the number of viable cells [34].

\subsection{Adipocyte Differentiation}

MSCs after the third passage cells were seeded in 12-well plates at the density of $1 \times 10^{4} \mathrm{cells} / \mathrm{cm}^{2}$. To induce differentiation, confluent cells were incubated for 14 days with STEM PRO ${ }^{\circledR}$ adipogenesis differentiation medium (Thermo Fisher Scientific Cat No A1007001, previously marketed by Invitrogen, Lifetecnologies and Gibco, Monza, Italy). Control cells were cultured for proliferation in MesenPRO $\mathrm{RS}^{\mathrm{TM}}$ medium (Thermo Fisher Scientific) [29] representing non-induced (NI) MSCs controls.

\subsection{Oil Red O Staining}

Cells were washed twice with PBS and fixed with precooled 10\% formaldehyde for $15 \mathrm{~min}$ at $-20^{\circ} \mathrm{C}$. After fixation, the cells were washed twice with PBS, stained for $30 \mathrm{~min}$ at room temperature in freshly diluted Oil Red O Solution $0.5 \%$ in isopropanol diluted at 3:2 with distilled water, filtered with a $0.45 \mu \mathrm{m}$ filter (O1391-Sigma), and then washed twice with distilled water. Oil Red $\mathrm{O}$ is a lysochrome (fat-soluble dye) diazo dye used for the selective staining and detection of neutral triglycerides and lipids contained in lipid droplets of cultured cells. Images were acquired using a bright-field microscope (EVOS M5000 Cell Imaging System, Life Technologies) [29].

\subsection{RNA Isolation, Reverse Transcription and Quantitative RT-PCR}

The TRI Reagent was used for RNA extraction (Sigma-Aldrich) and quantified with the NanoDrop 2000/2000c Spectrophotometer (Thermo Fisher Scientific) and the quality was monitored using 1.5\% agarose gels run in MOPS buffer, pH 7.1 (0.4 M MOPS (3-( $N$ morpholino)propanesulfonic acid), $0.1 \mathrm{M} \mathrm{NaAc}, 20 \mathrm{mM}$ EDTA (Ethylenediaminetetraacetic acid)), and 10\% formaldehyde. cDNA was synthesized from $1 \mu \mathrm{g}$ RNA using SuperScript III reverse transcriptase at $42{ }^{\circ} \mathrm{C}$ and $2.5 \mu \mathrm{M}$ random hexamers (Life Technologies). Quantitative RT-PCR (Q-RT-PCR) was performed using the SYBR ${ }^{\mathrm{TM}}$ Green master mix (Bio-Rad, Milan, Italy) and the iQ5 multicolor detection system (Bio-Rad). One cycle of $3 \mathrm{~min}$ at $95{ }^{\circ} \mathrm{C}$ was followed by 45 cycles of $10 \mathrm{~s}$ at $95{ }^{\circ} \mathrm{C}, 10 \mathrm{~s}$ at $60^{\circ} \mathrm{C}$, and $20 \mathrm{~s}$ at $72{ }^{\circ} \mathrm{C}$, followed by a melting curve. mRNA levels are normalized to GAPDH expression as described in [35], and $2^{-\Delta \Delta C t}$ values calculated. Relative gene expression was determined using the comparative threshold cycle $\mathrm{Ct}$ method, normalizing for housekeeping genes (GAPDH) such that the average the expression ratio was calculated as $2^{-\mathrm{ddCt}}$. The primers for adipocyte specific gene amplification were: PPAR $\gamma 2$, FWD CCTATTGACCCAGAAAGCGATT, REV CATTACGGAGAGATCCACGGA); FABP4 (FWD TGGGCCAGGAATTTGACGAA, (REV GACGCATTCCACCACCAGTT); ADIPO-Q, FWD AGGGTGAGAAAGGAGATCC, REV GGCATGTTGGGGATAGTAA.

\subsection{Statistics}

All results are reported as mean \pm standard deviation (SD). Statistical analysis was performed using $t$-test $(* p<0.05$ were considered statistically significant). 


\section{Conclusions}

Here, we compared the ability of NPO-MSCs and CTL-MSCs from patients to differentiate into mature adipocytes. Although NPO-MSCs and CTL-MSCs show the same the typical antigen expression pattern of mesenchymal stromal cells, when they are cultivated under adipocyte conditions, they show different fates. CTL-MSCs were able to differentiate into mature adipocytes characterized by roughly spherical shape and ectopic fat deposits. Instead, the NPO-MSCs were apparently committed only to preadipocytes and underwent growth arrest and consequent apoptosis.

In this study, we highlight that an adipocyte differentiation medium induces apoptosis in NPO-MSCs sparing control nasal mucosal tissue. The underlying mechanisms remain to be investigated and need further study to clarify the pathways involved which induce and sustain the programmed cell death programmed process.

Author Contributions: Conceptualization, analysis and interpretation data, writing-original draft preparation, E.C., N.L. (Nadia Lobello), N.L. (Nicola Lombardo), M.M. and H.M.B.; literature search, writing-editing, H.L.M., G.L.P. All authors have read and agreed to the published version of the manuscript.

Funding: This work was supported by fund from J18C17000620006 DEMOCEDE.

Conflicts of Interest: The authors declare no conflict of interest.

\section{Abbreviations}

$\begin{array}{ll}\text { CRS } & \text { Chronic rhinosinusitis } \\ \text { CRSsNP } & \text { CRS without nasal polyposis } \\ \text { CRSwNP } & \text { CRS with nasal polyposis } \\ \text { MHC-II } & \text { class of major histocompatibility complex } \\ \text { FACS } & \text { Fluorescence-activated Cell Sorting } \\ \text { PPARg2 } & \text { peroxisome proliferator-activated receptors } \\ \text { FABP4 } & \text { fatty acid binding protein 4 } \\ \text { ADIPO-Q } & \text { adiponectin } \\ \text { ADSCs } & \text { Adipose-derived stem cells } \\ \text { MPC } & \text { Mesenchymal progenitor cells } \\ \text { ABC1 } & \text { ATP Binding Cassette Subfamily A Member 1 } \\ \text { FGF10 } & \text { Fibroblast Growth Factor 10 } \\ \text { KDR } & \text { Kinase Insert Domain Receptor } \\ \text { GDF6 } & \text { Growth Differentiation Factor 6 } \\ \text { HLA-DR } & \text { human leukocyte antigen-D related } \\ \text { PDL1-2 } & \text { Programmed death-ligand 1-2 } \\ \text { EDTA } & \text { Ethylenediaminetetraacetic acid } \\ \text { FITC } & \text { Fluorescein isothiocyanate } \\ \text { GADPH } & \text { Glyceraldehyde-3-phosphate dehydrogenase } \\ \text { MOPS } & \text { 3-(N-morpholino)propanesulfonic acid } \\ \text { PBS } & \text { Phosphate-buffered saline } \\ \text { MesenPRO RSTM } & \text { Mesenchymal Proliferation reduced serum Trade Mark } \\ & \end{array}$

\section{References}

1. Schneider, S.; Campion, N.J.; Villazala-Merino, S.; Liu, D.T.; Bartosik, T.; Landegger, L.D.; Ahmadi, N.; Mueller, C.A.; Vyskocil, E.; Stanek, V.; et al. Associations between the Quality of Life and Nasal Polyp Size in Patients Suffering from Chronic Rhinosinusitis without Nasal Polyps, with Nasal Polyps or Aspirin-Exacerbated Respiratory Disease. J. Clin. Med. 2020, 9, 925. [CrossRef]

2. Fokkens, W.J.; Lund, V.J.; Mullol, J.; Bachert, C.; Alobid, I.; Baroody, F.; Cohen, N.; Cervin, A.; Douglas, R.; Gevaert, P.; et al. EPOS 2012: European position paper on rhinosinusitis and nasal polyps 2012. A summary for otorhinolaryngologists. Rhinology 2012, 50, 1-12. [CrossRef] 
3. Fokkens, W.J.; Lund, V.J.; Hopkins, C.; Hellings, P.W.; Kern, R.; Reitsma, S.; Toppila-Salmi, S.; Bernal-Sprekelsen, M.; Mullol, J.; Alobid, I.; et al. European position paper on rhinosinusitis and nasal polyps. Rhinology 2020, 58 (Suppl. S29), 1-464. [CrossRef]

4. Koennecke, M.; Klimek, L.; Mullol, J.; Gevaert, P.; Wollenberg, B. Subtyping of polyposis nasi: Phenotypes, endotypes and comorbidities. Allergo J. Int. 2018, 27, 56-65. [CrossRef]

5. Ahern, S.; Cervin, A. Inflammation and Endotyping in Chronic Rhinosinusitis-A Paradigm Shift. Medicina 2019, 55, 95. [CrossRef]

6. Wynne, M.; Atkinson, C.; Schlosser, R.J.; Mulligan, J.K. Contribution of Epithelial Cell Dysfunction to the Pathogenesis of Chronic Rhinosinusitis with Nasal Polyps. Am. J. Rhinol. Allergy 2019, 33, 782-790. [CrossRef]

7. Wang, X.; Zhang, N.; Bo, M.; Holtappels, G.; Zheng, M.; Lou, H.; Wang, H.; Zhang, L.; Bachert, C. Diversity of TH cytokine profiles in patients with chronic rhinosinusitis: A multicenter study in Europe, Asia, and Oceania. J. Allergy Clin. Immunol. 2016, 138, 1344-1353. [CrossRef]

8. Lou, H.; Zhang, N.; Bachert, C.; Zhang, L. Highlights of eosinophilic chronic rhinosinusitis with nasal polyps in definition, prognosis, and advancement. Int. Forum Allergy Rhinol. 2018, 8, 1218-1225. [CrossRef]

9. Pelaia, C.; Calabrese, C.; Vatrella, A.; Busceti, M.T.; Garofalo, E.; Lombardo, N.; Terracciano, R.; Pelaia, G. Benralizumab: From the Basic Mechanism of Action to the Potential Use in the Biological Therapy of Severe Eosinophilic Asthma. Biomed. Res. Int. 2018, 2018, 4839230. [CrossRef]

10. Ren, L.; Zhang, N.; Zhang, L.; Bachert, C. Biologics for the treatment of chronic rhinosinusitis with nasal polyps-State of the art. World Allergy Organ. J. 2019, 12, 100050. [CrossRef]

11. Bachert, C.; Han, J.K.; Desrosiers, M.; Hellings, P.W.; Amin, N.; Lee, S.E.; Mullol, J.; Greos, L.S.; Bosso, J.V.; Laidlaw, T.M.; et al. Efficacy and safety of dupilumab in patients with severe chronic rhinosinusitis with nasal polyps (LIBERTY NP SINUS-24 and LIBERTY NP SINUS-52): Results from two multicentre, randomised, double-blind, placebo-controlled, parallel-group phase 3 trials. Lancet 2019, 394, 1638-1650. [CrossRef]

12. Lombardo, N.; Pelaia, C.; Ciriolo, M.; Della Corte, M.; Piazzetta, G.; Lobello, N.; Viola, P.; Pelaia, G. Real-life effects of benralizumab on allergic chronic rhinosinusitis and nasal polyposis associated with severe asthma. Int. J. Immunopathol. Pharmacol. 2020, 34, 2058738420950851. [CrossRef]

13. Gevaert, P.; Omachi, T.A.; Corren, J.; Mullol, J.; Han, J.; Lee, S.E.; Kaufman, D.; Ligueros-Saylan, M.; Howard, M.; Zhu, R.; et al. Efficacy and safety of omalizumab in nasal polyposis: 2 randomized phase 3 trials. J. Allergy Clin. Immunol. 2020, 146, 595-605. [CrossRef]

14. Chiarella, E.; Lombardo, N.; Lobello, N.; Aloisio, A.; Aragona, T.; Pelaia, C.; Scicchitano, S.; Bond, H.M.; Mesuraca, M. Nasal Polyposis: Insights in Epithelial-Mesenchymal Transition and Differentiation of Polyp Mesenchymal Stem Cells. Int. J. Mol. Sci. 2020, 21, 6878. [CrossRef]

15. Klimek, L.; Koennecke, M.; Mullol, J.; Hellings, P.W.; Wang, D.Y.; Fokkens, W.; Gevaert, P.; Wollenberg, B. A possible role of stem cells in nasal polyposis. Allergy 2017, 72, 1868-1873. [CrossRef]

16. de Oliveira, P.W.; Pezato, R.; Agudelo, J.S.; Perez-Novo, C.A.; Berghe, W.V.; Câmara, N.O.; de Almeida, D.C.; Gregorio, L.C. Nasal Polyp-Derived Mesenchymal Stromal Cells Exhibit Lack of Immune-Associated Molecules and High Levels of Stem/Progenitor Cells Markers. Front. Immunol. 2017, 8, 39. [CrossRef]

17. Cho, J.S.; Park, J.H.; Kang, J.H.; Kim, S.E.; Park, I.H.; Lee, H.M. Isolation and characterization of multipotent mesenchymal stem cells in nasal polyps. Exp. Biol. Med. 2015, 240, 185-193. [CrossRef]

18. Koennecke, M.; Böscke, R.; Pfannerstill, A.C.; Reers, S.; Elsner, M.; Fell, B.; Richter, A.; Bruchhage, K.L.; Schumann, S.; Pries, R.; et al. Neuronal Differentiation Capability of Nasal Polyps of Chronic Rhinosinusitis. Arch. Immunol. Ther. Exp. 2017, 65, 431-443. [CrossRef]

19. Di Vito, A.; Giudice, A.; Chiarella, E.; Malara, N.; Bennardo, F.; Fortunato, L. In Vitro Long-Term Expansion and High Osteogenic Potential of Periodontal Ligament Stem Cells: More Than a Mirage. Cell Transplant. 2019, 28, 129-139. [CrossRef]

20. Chiarella, E.; Aloisio, A.; Scicchitano, S.; Lucchino, V.; Montalcini, Y.; Galasso, O.; Greco, M.; Gasparini, G.; Mesuraca, M.; Bond, H.M.; et al. ZNF521 Represses Osteoblastic Differentiation in Human Adipose-Derived Stem Cells. Int. J. Mol. Sci. 2018, 19, 4095. [CrossRef]

21. Amable, P.R.; Teixeira, M.V.; Carias, R.B.; Granjeiro, J.M.; Borojevic, R. Gene expression and protein secretion during human mesenchymal cell differentiation into adipogenic cells. BMC Cell Biol. 2014, 15, 46. [CrossRef]

22. Moseti, D.; Regassa, A.; Kim, W.-K. Molecular Regulation of Adipogenesis and Potential Anti-Adipogenic Bioactive Molecules. Int. J. Mol. Sci. 2016, 17, 124. [CrossRef] 
23. Prentice, K.J.; Saksi, J.; Hotamisligil, G.S. Adipokine FABP4 integrates energy stores and counterregulatory metabolic responses. J. Lipid Res. 2019, 60, 734-740. [CrossRef]

24. Dominici, M.; Le Blanc, K.; Mueller, I.; Slaper-Cortenbach, I.; Marini, F.; Krause, D.; Slaper-Cortenbach, I.; Marini, F.; Krause, D.; Deans, R.; et al. Minimal criteria for defining multipotent mesenchymal stromal cells: The International Society for Cellular Therapy position statement. Cytotherapy 2006, 8, 315-317. [CrossRef]

25. Afanasyev, B.V.; Elstner, E.E.; Zander, A.R.A.J. Friedenstein, founder of the mesenchymal stem cell concept. Cell. Ther. Transplant. 2009, 1, 3. [CrossRef]

26. Berebichez-Fridman, R.; Montero-Olvera, P.R. Sources and Clinical Applications of Mesenchymal Stem Cells: State-of-the-art review. Sultan. Qaboos Univ. Med. J. 2018, 18, e264-e277. [CrossRef]

27. Cristancho, A.; Lazar, M. Forming functional fat: A growing understanding of adipocyte differentiation. Nat. Rev. Mol. Cell Biol. 2011, 12, 722-734. [CrossRef]

28. Bahmad, H.F.; Daouk, R.; Azar, J.; Sapudom, J.; Teo, J.C.M.; Abou-Kheir, W.; Al-Sayegh, M. Modeling Adipogenesis: Current and Future Perspective. Cells 2020, 9, 2326. [CrossRef]

29. Chiarella, E.; Aloisio, A.; Codispoti, B.; Nappo, G.; Scicchitano, S.; Lucchino, V.; Montalcini, Y.; Camarotti, A.; Galasso, O.; Greco, M.; et al. ZNF521 Has an Inhibitory Effect on the Adipogenic Differentiation of Human Adipose-Derived Mesenchymal Stem Cells. Stem. Cell Rev. Rep. 2018, 14, 901-914. [CrossRef]

30. Cho, K.S.; Park, H.Y.; Roh, H.J.; Bravo, D.T.; Hwang, P.H.; Nayak, J.V. Human ethmoid sinus mucosa: A promising novel tissue source of mesenchymal progenitor cells. Stem. Cell Res. Ther. 2014, 5, 15. [CrossRef]

31. Bernaudo, F.; Monteleone, F.; Mesuraca, M.; Krishnan, S.; Chiarella, E.; Scicchitano, S.; Cuda, G.; Morrone, G.; Bond,H.M.; Gaspari, M. Validation of a novel shotgun proteomic workflow for the discovery of protein-protein interactions: Focus on ZNF521. J. Proteome Res. 2015, 14, 1888-1899. [CrossRef]

32. Codispoti, B.; Rinaldo, N.; Chiarella, E.; Lupia, M.; Spoleti, C.B.; Marafioti, M.G.; Aloisio, A.; Scicchitano, S.; Giordano, M.; Nappo, G.; et al. Recombinant TAT-BMI-1 fusion protein induces ex vivo expansion of human umbilical cord blood-derived hematopoietic stem cells. Oncotarget 2017, 8, 43782-43798. [CrossRef]

33. Chiarella, E.; Codispoti, B.; Aloisio, A.; Cosentino, E.G.; Scicchitano, S.; Montalcini, Y.; Lico, D.; Morrone, G.; Mesuraca, M.; Bond, H.M. Zoledronic acid inhibits the growth of leukemic MLL-AF9 transformed hematopoietic cells. Heliyon 2020, 6, e04020. [CrossRef]

34. Di Vito, A.; Chiarella, E.; Baudi, F.; Scardamaglia, P.; Antonelli, A.; Giudice, D.; Barni, T.; Fortunato, L.; Giudice, A. Dose-dependent effects of zoledronic acid on human periodontal ligament stem cells: An in vitro pilot study. Cell Transplant. 2020, 29, 963689720948497. [CrossRef]

35. Scicchitano, S.; Giordano, M.; Lucchino, V.; Montalcini, Y.; Chiarella, E.; Aloisio, A.; Codispoti, B.; Zoppoli, P.; Melocchi, V.; Bianchi, F.; et al. The stem cell-associated transcription co-factor, ZNF521, interacts with GLI1 and GLI2 and enhances the activity of the Sonic hedgehog pathway. Cell Death Dis. 2019, 10, 715. [CrossRef]

Publisher's Note: MDPI stays neutral with regard to jurisdictional claims in published maps and institutional affiliations.

(C) 2020 by the authors. Licensee MDPI, Basel, Switzerland. This article is an open access article distributed under the terms and conditions of the Creative Commons Attribution (CC BY) license (http://creativecommons.org/licenses/by/4.0/). 